\title{
PERENCANAAN PENGGUNAAN MATERIAL PLASTIK DAUR ULANG DENGAN SISTEM MANUFAKTUR BERKELANJUTAN DI POLITEKNIK MANUFAKTUR ASTRA
}

\author{
Komarudin dan Neilinda Novita Aisa \\ Program Studi Teknik Industri Fakultas Teknologi Industri \\ Institut Sains dan Teknologi Nasional \\ komarudin.mt@gmail.com
}

\begin{abstract}
One of many kinds of production processes in Politeknik Manufaktur Astra is Plastic Injection Process with ABS material. This process will produce plastic and scrap. The amount of plastic scrap that is produced by this process reaches $50 \%$ of all of the amount. To increase the efficiency of ABS material and build up the culture of Sustainable Development System so that is done a kind of research that is focused on the utilization of plastic waste material from Process of Plastic Injection by doing a recycle process and using the product of recycle as the basic additive material in Plastic Injection Process. To figure out the properness of the material of recycled plastic as the main material in Plastic Injection Process so is also done a tensile test to any composition of recycled ABS material and valuing certain mechanical properties that are similar to original ABS material. Moreover to cut the cost of ABS material providing so is done an analysis of material reservation with EOQ method to figure out the economic number of material reservation. The calculation of EOQ showed the most economic amount per reserving is $75 \mathrm{~kg} /$ reserve. By the utilization of recycled material and usage of EOQ method on providing the ABS material so that Politeknik Manufaktur Astra can do a cost reduction for $36 \%$.
\end{abstract}

Key Words : Injection Process, ABS Material. Recycle, EOQ

\section{PENDAHULUAN}

Perhatian terhadap masalah lingkungan hidup mulai meningkat dan menjadi isu global ketika konferensi PBB mengenai lingkungan hidup pertama diadakan pada tanggal 5 Juni 1972 di Stockholm, Swedia.Pada pertemuan tersebut, negara-negara sepakat memperbaiki lingkungan dan menyelamatkan bumi. Kemudian diadakanlah KTT Bumi pada tanggal 12-14 Juni 1992 yang mengeluarkan himbauan untuk menerapkan konsep pembangunan yang berwawasan lingkungan atau biasa disebut Sustainable Development atau pembangunan yang berkelanjutan.

Di Politeknik Manufaktur Astra atau Polman Astra proses produksi plastik cetak injeksi menggunakan dua material yaitu Polypropilena (PP) dan Acrylonitrile Butadine Styrene (ABS) dimana ABS menjadi material yang paling banyak digunakan. Proses produksi menghasilkan produk yang OK dan yang NG (no good) atau cacat. Jumlah produk NG bisa mencapai 50\% dari hasil produk yang diproduksi karena skill operator yang belum mumpuni. Produk-produk yang NG menjadi limbah plastik yang tidak lagi digunakan. Ditambah scrap plastik yang dihasilkan dari produk OK maka limbah yang dihasilkan bertambah.

Untuk itu, dilakukan penelitian yang akan difokuskan pada pemanfaatan limbah plastik dari proses cetak injeksi untuk meningkatkan efisiensi material plastik dengan melakukan proses daur ulang material dan membangun budaya manufaktur berkelanjutan.

Salah satu caranya dengan melakukan proses daur ulang dan menggunakan limbah plastik hasil daur ulang sebagai campuran material dasar pada proses cetak injeksi plastik. Dengan adanya penelitian ini diharapkan dapat mengurangi jumlah pemakaian material plastik baru dengan memanfaatkan limbah plastik yang dihasilkan dari proses produksi serta dapat menerapkan sistem manufaktur berkelanjutan di Polman Astra. TINJAUAN PUSTAKA

Pengertian Sustainable Development

Berdasarkan tata bahasa, pengertian kata 
sustainable pada dasarnyadapat diartikan juga dengan capable of being sustained atau kemampuan untuk tetap berkelanjutan, sedangkan kata development diartikan sebagai pembangunan. Jadi, secara bahasa pengertian sustainable development dapat diartikan sebagai pembangunan berkelanjutan.

\section{Dasar Tuntutan Penerapan Sistem Produksi Berkelanjutan}

Dalam beberapa dekade terakhir, kesadaran manusia akan arti lingkungan semakin besar. Industri dituntut untuk bekerja tanpa merusak lingkungan.Untuk mendapatkan pelanggan, perusahaan perlu memiliki pengetahuan yang komprehensif mengenai lingkungan bisnisnya. Pemahaman yang baik atas kondisi lingkungan akan mengarahkan kebijakan dan keputusan pemasaran berkemampuan mengantisipasi strategi pemasaran yang diterapkan oleh pesaingnya. Siklus Material Plastik plastik

Berikut adalah proses pembuatan material

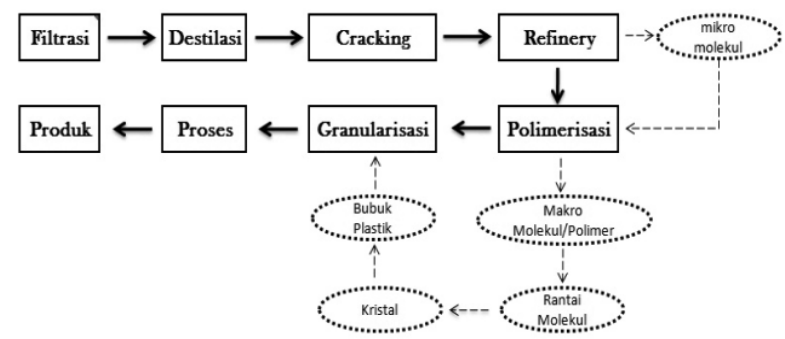

Gambar 2.1 Diagram Proses Pembuatan Material Plastik

\section{Pengertian Limbah}

Limbah adalah buangan yang dihasilkan dari suatu proses produksi baik industri maupun domestik (rumah tangga).Dimana masyarakat bermukim, disanalah berbagai jenis limbah akan dihasilkan. Limbah padat lebih dikenal sebagai sampah, yang seringkali tidak dikehendaki kehadirannya karena tidak memiliki nilai ekonomis. Bila ditinjau secara kimiawi, limbah ini terdiri dari ba-han kimia Senyawa organik dan Senyawa anorganik.

\section{Pengolahan Material Plastik Daur Ulang}

Secara umum, terdapat empat (4) persyaratan agar sampah plastik dapat diproses oleh sebuah industri, antara lain: (Gugun Gunawan, 2007: 20)

1. Sampah plastik harus berbentuk tertentu.

2. Harus homogen.

3. Tidak terkontaminasi oleh zat-zat kimia yang dapat menurunkan kualitas produk yang dihasilkan, dan
4. Diupayakan tidak teroksidasi.

Berikut adalah tahapan pendaurulangan sampah plastik menjadi biji plastik:

1. Pemisahan: sampah plastik harus dipisahkan dari material sampah lainnya

2. Pemotongan: sampah plastik yang sudah dipisahkan kemudian dipotong-potong sesuai dengan kebutuhan.

3. Pencucian; sampah plastik yang sudah menjdi potongan-potongan ini harus dicuci untuk membersihkannya dari zat-zat tertentu yang tidak dibutuhkan

4. Penggilingan; setelah dicuci, sampah plastik kemudian digiling agar menjadi biji plastik.

5. Biji plastik yang telah diolah inilah yang akan dikirim ke pabrik pengolahan produkproduk daur ulang.

\section{Proses Injeksi Plastik}

Injection molding adalah proses pembuatan part-part yang berlainan, yang dapat memiliki penampang yang kompleks dan bervariasi, serta berbagai tekstur dan karakteristik permukaan dengan cara menyuntikkan material plastik leleh ke dalam mold mengguanakan screw.

\section{Cacat Proses Injeksi Plastik}

Tabel 2.1 Cacat Injeksi Plastik

\begin{tabular}{|c|c|c|c|c|c|}
\hline No & Nama & Ilustrasi & Diskripsi & Penyebab & Solusi \\
\hline 1 & Silver Streak & & $\begin{array}{lr}\text { Cacat yang } \\
\text { berbentuk garis } \\
\text { berwama perak } \\
\text { dan memanjang } \\
\text { searah dengan } \\
\text { aliran injelssi. }\end{array}$ & $\begin{array}{l}\text { - Material basah } \\
\text { - Udara terjebal: } \\
\text { di nozzle. }\end{array}$ & $\begin{array}{l}\text { - Keringkam } \\
\text { material } \\
\text { - Kurangi suck } \\
\text { back }\end{array}$ \\
\hline 2 & $\begin{array}{l}\text { Short Shot } \\
\text { atau Short } \\
\text { Mold }\end{array}$ & & $\begin{array}{l}\text { Pengisian yang } \\
\text { tidak sempuma } \\
\text { pada cavity yang } \\
\text { menyebablsan } \\
\text { produl tidak } \\
\text { sempuma. }\end{array}$ & $\begin{array}{l}\text { - Ukuran runner } \\
\text { tidak } \\
\text { menculupi } \\
\text { - Bentuk saluram } \\
\text { terlalu rumit } \\
\text { - Charging } \\
\text { stroke teralu } \\
\text { pendel. } \\
\text { - Kecepatan } \\
\text { injelssi terlalu } \\
\text { rendah } \\
\end{array}$ & $\begin{array}{l}\text { - Repair mold } \\
\text { - Perpanjang } \\
\text { Charging } \\
\text { stroke } \\
\text { - Naikksan } \\
\text { kecapatan } \\
\text { injeksi } \\
\text { - Sesuaiakan } \\
\text { setting } \\
\text { parameter } \\
\text { dengan produlk }\end{array}$ \\
\hline 3 & Flosh & & $\begin{array}{l}\text { Laspisan tipis yang } \\
\text { keluar dari cavity } \\
\text { mold pada bagian } \\
\text { parting line atan } \\
\text { padalobasi ejector } \\
\text { pin. }\end{array}$ & \begin{tabular}{|l|} 
- Kecapatan dan \\
teksanan injeksi \\
terlalu tinggi. \\
- Charging \\
stroke terlalu \\
panjang. \\
- Suhu material \\
terlalu tinggi. \\
- Mold disfungsi
\end{tabular} & $\begin{array}{l}\text { - Kurangi } \\
\text { kecepatan dan } \\
\text { teksanan injelssi } \\
\text { - Perpendek: CS } \\
\text { - Turunkan suhu } \\
\text { material } \\
\text { - Periksa kondiai } \\
\text { mold }\end{array}$ \\
\hline 4 & Weld Line & & $\begin{array}{lr}\text { Garis yang } \\
\text { terbentuk alkibat } \\
\text { pertemuan dua } \\
\text { aliran material }\end{array}$ & $\begin{array}{l}\text { - Multi gate } \\
\text { - Temperatur } \\
\text { melt material } \\
\text { terlalu rendah } \\
\text { - Temperatur } \\
\text { mold rendah }\end{array}$ & $\begin{array}{l}- \text { - Naiklksan } \\
\text { temperature } \\
\text { melt material } \\
\text { - Naikksan } \\
\text { temperature } \\
\text { mold } \\
\end{array}$ \\
\hline 5 & Flow Line & & $\begin{array}{l}\text { Cacat permuksen } \\
\text { yang berupa } \\
\text { gelombang } \\
\text { melingkar di } \\
\text { selvitar area gate. }\end{array}$ & $\begin{array}{l}\text { - Temperatur } \\
\text { material dan } \\
\text { mold terlalu } \\
\text { rendah. } \\
\text { - Kecepatan } \\
\text { injelksi rendah }\end{array}$ & $\begin{array}{l}\text { - Naijlksan } \\
\text { temperature } \\
\text { material dan } \\
\text { mold. } \\
\text { - Naillkan } \\
\text { kecepatan } \\
\text { injelksi. }\end{array}$ \\
\hline 6 & Sink Mark & & $\begin{array}{l}\text { Pengkerutan yang } \\
\text { terjadi pada area } \\
\text { yang memiliki } \\
\text { ketebalan yang } \\
\text { berbeda }\end{array}$ & $\begin{array}{l}\text { - Penyusutan } \\
\text { thermal produl } \\
\text { - Waktu cooling } \\
\text { dan holding } \\
\text { terlalu rendah } \\
\text { - Terperatur melt }\end{array}$ & $\begin{array}{l}\text { - Naiklkan waktu } \\
\text { cooling dan } \\
\text { holding } \\
\text { - Turunkan } \\
\text { temperature } \\
\text { melt }\end{array}$ \\
\hline
\end{tabular}




\section{Pengenalan Material ABS}

Akrilonitril butadiena stirena atau yang lebih dikenal dengan nama $\mathrm{ABS}$ dengan rumus kimia $(\mathrm{C} 8 \mathrm{H} 8) \mathrm{x} \cdot(\mathrm{C} 4 \mathrm{H} 6) \mathrm{y} \cdot(\mathrm{C} 3 \mathrm{H} 3 \mathrm{~N}) \mathrm{z})$ adalah polimer termoplastik umum. ABS memiliki suhu transisi gelas (Tg) sekitar $105^{\circ} \mathrm{C}\left(221^{\circ} \mathrm{F}\right)$. ABS memiliki kristal amorf.

Berikut adalah kekuatan mekanis material ABS:

Tabel 2.2 Spesifikasi Material ABS

\begin{tabular}{|c|c|c|c|c|c|c|}
\hline $\begin{array}{c}\text { Spesific } \\
\text { Gravity }\end{array}$ & $\begin{array}{c}\text { Processing } \\
\text { Temperatur } \\
\left.{ }^{0} \mathrm{~F}{ }^{\circ} \mathrm{C}\right)\end{array}$ & $\begin{array}{c}\text { Tensile } \\
\text { Strength } \\
\text { Psi (MPa) }\end{array}$ & $\begin{array}{c}\text { Elongation } \\
\text { at Break } \\
(\%)\end{array}$ & $\begin{array}{c}\text { Flexural } \\
\text { Stength } \\
\text { Psi (MPa) }\end{array}$ & $\begin{array}{c}\text { Flexural } \\
\text { Modulus } \\
\text { Psi (MPa) }\end{array}$ & $\begin{array}{c}\text { Izod Impact } \\
\text { Ft-1b/in (J/m) }\end{array}$ \\
\hline 1.20 & $420(215)$ & $\begin{array}{c}6000 \\
(41.4)\end{array}$ & 50 & $\begin{array}{c}10000 \\
(68.9)\end{array}$ & $450(3.10)$ & $6.0(320)$ \\
\hline \multicolumn{7}{|c|}{ Sumber: Strong, A. Brent. Plastiks Material and Processing, Pearson } \\
\hline
\end{tabular}

\section{Material Requirements Planning (MRP)}

Material Requirement Planning (MRP) adalah suatu sistem perencanaan dan penjadwalan kebutuhan material untuk produksi yang memerlukan beberapa tahapan proses atau fase. Berdasar kan definisi dan unsur penting yang dijumpai dalam MRP, berikut disajikan kerangka umum model MRP.

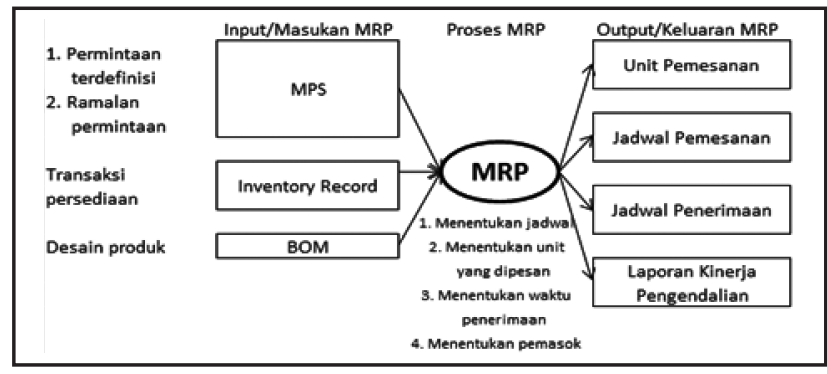

Gambar 2.2 Kerangka Umum Model MRP

\section{Economic Order Quantity (EOQ)}

Persediaan optimum, seperti yang telah dikemukanan, akan dicapai pada titil leseimbangan antara biaya penyimpanan dan biaya pemesanan. Secara matematis, keseimbangan tersebut dapat dirumuskan melalui persamaan berikut:

$$
\begin{gathered}
\frac{D}{Q}(S)=\frac{Q}{2}(H) \text { sehing ga } 2 D S=Q^{2} H \\
Q^{2}=\frac{2 D S}{H} \text { dan EOQ }=\sqrt{\frac{2 D S}{H}}
\end{gathered}
$$

EOQ yaitu jumlah unit yang dipesan pada biaya yang paling murah atau optimal. Model ini memakai asumsi sebagai berikut:

1. Permintaan selama satu tahun (D) diketahui tetap dan tidak berubah.

2. Harga sediaan (C) diketahui tetap dan tidak berubah

3. Sediaan dianggap selalu tersedia sehingga dapat diperoleh setiap dibutuhkan.

4. Biaya sediaan diketahui tetap dan tidak berubah. Berdasarkan asumsi di atas, maka factor yang dianggap berubah-ubah ialah kuantitas pemesanan (Q) yang tergantung pada nilai factor : D, C, dan biaya-biaya sediaan.

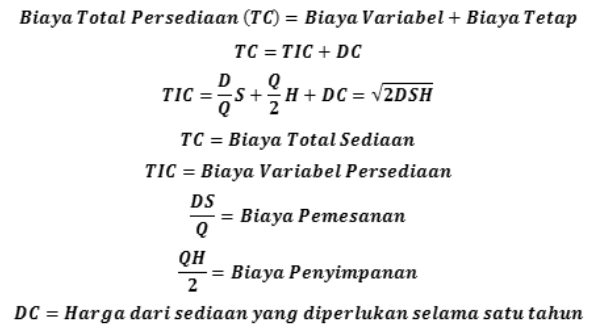

Berikut ini disajikan grafik yang menunjukkan hubungan antara kedua biaya tersebut, biaya penyimpanan dan biaya pemesanan.

\section{Model grafik dari konsep EOQ}

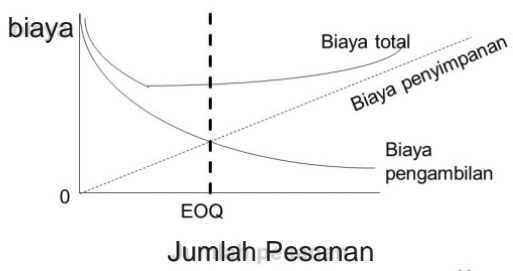

Gambar 2.3 Grafik EOQ

\section{Periodic Order Quantity(POQ)}

Pada penentuan unit pesanan berdasarkan periode tetap maka jumlah unit yang dipesan per order dapat saja berbeda dari setiap kali melakukan pemesanan, tetapi selang waktu penyampaian order tetap sama. Teknik POQ ini digunakan untuk menentukan interval waktu order (Economic Order Interval). Perhitungan metode POQ menggunakan rumus sebagi berikut:

$$
\begin{array}{r}
P O Q=Q=\sqrt{\frac{2 D S}{H[1-(d / p)]}} \\
\mathrm{TC}=\mathrm{SC}+\mathrm{HC}+\mathrm{PC} \\
=\frac{D}{Q} S+\frac{Q}{2} H+P D
\end{array}
$$

Dimana :

$\mathrm{d}=$ daily production rate (tingkat produksi per hari) $\mathrm{p}=$ daily demand rate (tingkat permintaan per hari)

\section{Lot for Lot (L4L)}

Pada metode ini unit yang disorder disesuaikan dengan jumlah kebutuhan bersih dalam periode yang bersangkutan.

Model L4L ini memiliki kesamaan dengan model kedua (POQ), yaitu jumlah unit yang 
disorder dapat saja bervariasi dari period ke periode dan sediaan pada akhir periode sama dengan nol.

\section{Metode Peramalan}

Peramalan adalah proses untuk memperkirakan beberapa kebutuhan yang akan datang dalam ukuran kuantitas, kualitas,waktu dan lokasi dalam rangka untuk memenuhi permintaan barang dan jasa.

\section{Pola Data}
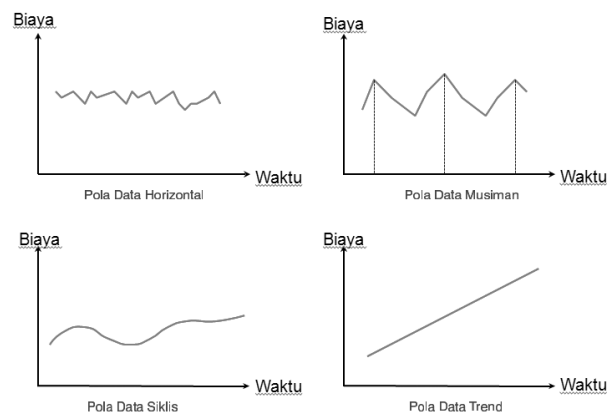

Gambar 2.5 Pola Data

Keterangan:

1. Pola Data Horizontal/Konstan : Data historis diplotkan terhadap waktu, fluktuasi random berharga konstan

2. Pola Data Musiman : Data historis diplotkan terhadap waktu, fluktuasi yang muncul secara reguler setiap tahun yang biasanya disebabkan oleh iklim.

3. Pola Data Siklis : muncul ketika data dipengaruhi oleh fluktuasi ekonomi jangka panjang, variasi siklis ini bisa terulang setelah jangka waktu tertentu.

4. Pola Data Trend/Linier : Data historis diplotkan terhadap waktu, fluktuasi random garis lurus yang menunjukkan pertumbuhan maupun penurunan terhadap waktu

\subsubsection{Teknik Peramalan Pola Data Konstan}

\section{Metode Least Square}

$$
\begin{aligned}
& y^{\prime}=a+b t \\
& a=\bar{d}-b \bar{t}
\end{aligned}
$$

$$
b=\frac{n \sum_{t=1}^{n} t d_{t}-\sum_{t=1}^{n} d_{t} \sum_{t=1}^{n} t}{n \sum_{t=1}^{n} t^{2}-\left(\sum_{t=1}^{n} t\right)^{2}}
$$

Metode Simple Average

$$
?=?=? ? ?
$$

\section{Single Moving Average}

\begin{tabular}{c|c|c}
\hline Time & Moving Average & Forecasting \\
\hline $\mathrm{t}$ & $\bar{d}=\frac{d_{1}+d_{2}+\ldots .+d_{t}}{t}$ & $d_{t+1}^{\prime}=\bar{d}=\sum_{i=1}^{t} d_{i} / t$ \\
$\mathrm{t}+1$ & $\bar{d}=\frac{d_{2}+d_{3}+\ldots .+d_{t+1}}{t}$ & $d_{t+1}^{\prime}=\bar{d}=\sum_{i=2}^{t+1} d_{i} / t$ \\
$\mathrm{t}+2$ & $\bar{d}=\frac{d_{3}+d_{4}+\ldots .+d_{t+2}}{t}$ & $d_{t+1}^{\prime}=\bar{d}=\sum_{i=3}^{t+2} d_{i} / t$ \\
\hline
\end{tabular}

\section{Teknik Peramalan Pola Data Trend} Simple Linear Regression

$$
b=\frac{n \sum_{t=1}^{n} t d_{t}-\sum_{t=1}^{n} d_{t} \sum_{t=1}^{n} t}{n \sum_{t=1}^{n} t^{2}-\left(\sum_{t=1}^{n} t\right)^{2}}
$$

Gunakan metode least square untuk memperoleh parameter $\mathrm{a}$ dan $\mathrm{b}$

$\mathrm{a}=$ Komponen yang tetap dari penjualan pada setiap tahun.

$\mathrm{b}=$ Tingkat perkembangan penjualan tiap tahun atau slope dari garis perkiraan penjualan

Double Moving Average

$$
\begin{aligned}
& S_{t}^{\prime \prime}=\frac{S_{t}^{\prime}+S_{t-1}^{\prime}+\ldots+S_{t-N+1}^{\prime}}{M} \\
& S_{t}^{\prime}=\frac{d_{1}+d_{2}+\ldots+d_{t-N+1}}{N} \\
& a_{t}=S_{t}^{\prime}+\left(S_{t}^{\prime}-S_{t}^{\prime \prime}\right) \\
& b_{t}=\frac{2}{N-1}\left(S_{t}^{\prime}-S_{t}^{\prime \prime}\right)
\end{aligned}
$$

Teknik Peramalan Pola Data Siklis

$$
d_{t}^{\prime}=a+u \cos \frac{2 \pi}{n} t+v \sin \frac{2 \pi}{n} t
$$

$\mathrm{n}$ : jumlah periode per siklus

Parameter a, u dan $\mathrm{v}$ dapat dicari dengan metode determinan matriks :

$$
\left|\begin{array}{cccc}
d^{\prime} & 1 & \cos \frac{2 \pi}{n} t & \sin \frac{2 \pi}{n} t \\
\sum d & n & 0 & 0 \\
\sum d \cos \frac{2 \pi}{n} t & 0 & \frac{n}{2} & 0 \\
\sum d \sin \frac{2 \pi}{n} t & 0 & 0 & \frac{n}{2}
\end{array}\right|=0
$$

2.10.5 Ukuran Kesalahan Peramalan

a. Mean Square Error

$$
M S E=\frac{\sum_{t=1}^{n}\left(d_{t}-D^{\prime}{ }_{t}\right)^{2}}{n}
$$


$a$

b.

$$
\begin{aligned}
& S E E=\sqrt{\sum_{t=1}^{n} \frac{\left(d_{t}-D_{t}^{\prime}\right)^{2}}{(n-f)}} \\
& \text { c. } \quad \text { Error Percentace } \\
& P E_{t}=\left(\frac{d_{t}-D_{t}^{\prime}}{d_{t}}\right) \times 100 \% \quad a=\bar{d}
\end{aligned}
$$

Keterangan : $\mathrm{f}=$ degree of freedom

- 1 untuk pola data konstan

- 2 untuk pola data trend

- 3 untuk pola data siklis

\section{METODE DAN PENGOLAHAN DATA \\ Alur Pelaksanaan Penelitian}

Penelitian ini dilakukan dengan langkah-langkah tahapan sebagai berikut :

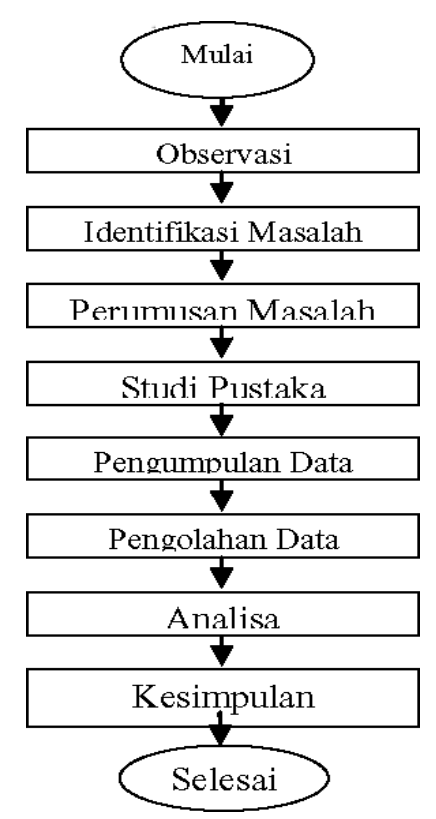

Gambar 3.1 Flowchart Tahapan Penelitian

\section{Metode Penelitian \\ Jenis Penelitian}

Jenis penelitian yang dilakukan adalah jenis penelitian deskriptif, yaitu studi untuk menggambarkan suatu keadaan terdahulu.Penelitian dilakukan dalam rangka untuk mencari fakta-fakta yang jelas tentang situasi dan kondisi aktivitas produksi perusahaan dengan pendekatan studi kasus.

\section{Obyek Penelitian}

Dalam penelitian ini peneliti akan membahas bagaimana cara meningkatkan efisiensi material plastik dengan melakukan proses daur ulang dalam rangka mengurangi dampak lingkungan hidup dengan sistem manufaktur berkelanjutan.

\section{Tempat dan Waktu Penelitian}

Penelitian dilakukan di Politeknik Manufaktur Astra yang memproduksi beberapa jenis produk dimana salah satu produknya adalah produk plastik yang berlokasi di Jl. Gaya Motor Raya No. 8 Sunter II-Jakarta 14330.Sedangkan penelitian dilakukan selama Januari - Juni 2015.

\section{Sumber Data}

Data yang diperoleh merupakan data numerik yang berkaitan dengan kegiatan produksi dan purchase order material plastik selama periode Januari-Juni 2015 yang berasal dari laporan divisi produksi dan purchase Politeknik ManufakturAstra.

\section{Variabel Penelitian \\ Persentase Kecacatan Produk}

Dalam proses produksi, tidak seluruh produksi hasilnya baik 100\% namun selalu ada kemungkinan beberapa produk cacat. Produk-produk cacat inilah yang nantinya akan didaur ulang untuk digunakan kembali menjadi bahan baku dengan persentase tertentu untuk memper-tahankan kualitas.

\section{Rencana Pemesanan Bahan Baku}

Perkiraan jumlah dan jenis bahan baku serta bahan pembantu yang akan dibutuhkan untuk dilakukan pemesanan guna memenuhi kebutuhan produksi didasarkan pada kebutuhan bersih produksi dengan penyesuaian lead time.

\section{Biaya Pengendalian Persediaan Bahan Baku}

Sebagai obyek perhitungan dan indikator hasil analisis, pengambilan keputusan penentuan besarnya jumlah persediaan didasarkan pada pertimbangan biaya-biaya variabel berikut ini:

\section{Biaya Penyimpanan (holding cost)}

Biaya yang berkaitan dengan menyimpan atau membawa persediaan selama waktu tertentu.

\section{Biaya Pemesanan (ordering cost)}

Mencakup biaya dari persediaan, formulir, proses pemesanan, pembelian, dukungan administrasi, dan seterusnya.

\section{Biaya Penyetelan (setup cost)}

Biaya untuk mempersiapkan sebuah mesin 
dan atau proses untuk melakukan proses daur ulang yang juga menyertakan waktu kerja mesin dan tenaga kerja untuk melakukan proses daur ulang.

\section{Catatan Persediaan Bahan Baku}

Informasi data persediaan pendukung variabel penelitian meliputi struktur produk, jumlah dan jenis kebutuhan persediaan ditangan, jumlah persediaan pengaman dan lead time setiap komponen produk.

\section{Alat Analisis Data}

Alat analisis yang dipakai adalah Sistem Perencanaan dan Pengendalian Bahan Baku (Material requirement Planning-MRP).Sebelum sampai pada proses perhitungan MRP, dilakukan terlebih dahulu peramalan permintaan sebagai masukan MRP. Dengan demikian, hasil perhitungan MRP dapat dijadikan bahan evaluasi atau pertimbangan pengambilan keputusan yang tepat dalam melakukan perencanaan dan pengendalian persediaan bahan baku guna kelancaran proses produksi dengan keputusan yang efisien dari segi biaya serta ketepatan waktu.

\section{Alat yang Digunakan}

Mesin Plastik Injeksi Hwa Chin 160 Ton

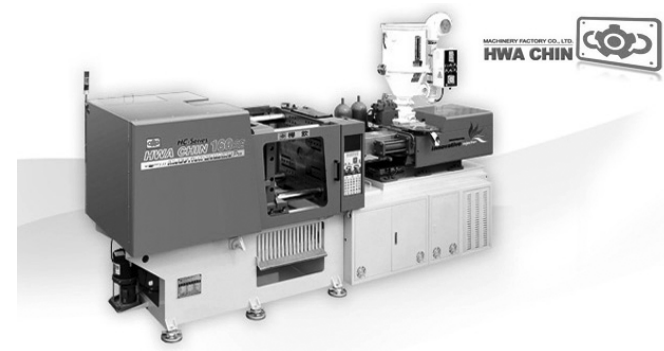

Gambar 3.2 Mesin Plastik Injeksi Hwa Chin 160 Ton

Tabel 3.1 Tabel Spesifikasi Mesin Injeksi Hwa Chin 160 Ton

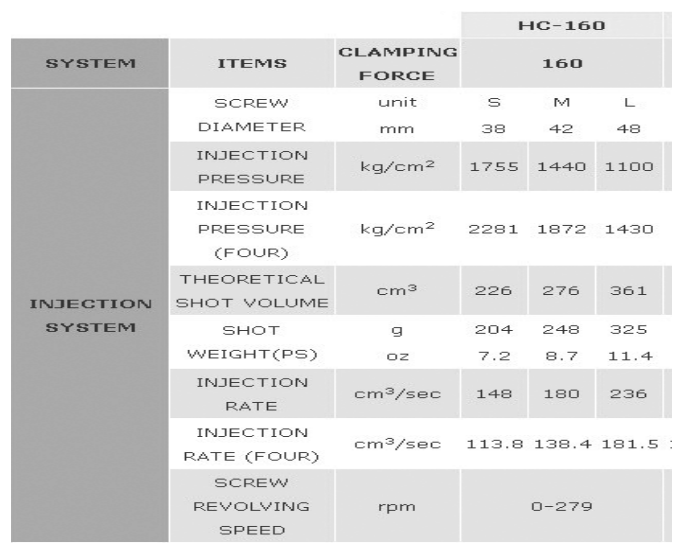

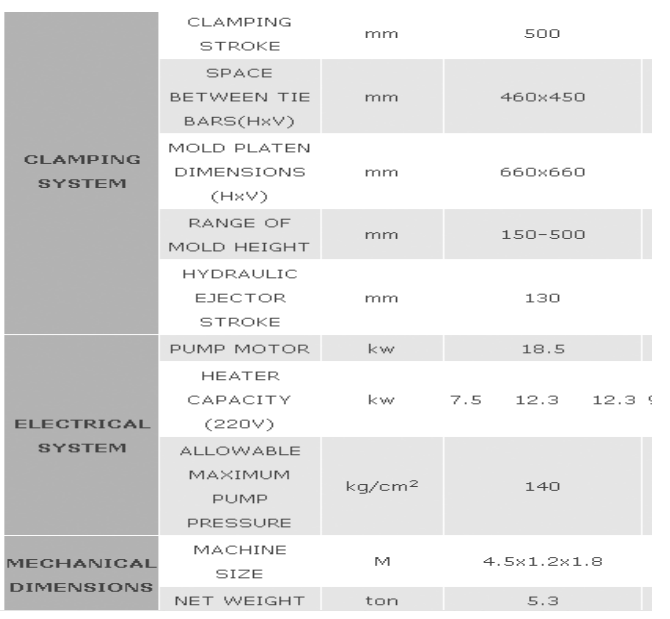

HSS Plastik Granular Sumida Series 07039

Gambar 3.5 HSS Plastik Granular Sumida Series 07039

Sumber: www.Nbhuare.en.alibaba.com

Spesifi-kasi mesin seperti berikut :

$\begin{array}{ll}\text { Voltage } & : 380 \mathrm{~V} \\ \text { Weight } & : 660 \mathrm{~kg} \\ \text { Power } & : 7.5 \mathrm{kw} \\ \text { Frequency } & : 50 \mathrm{~Hz}\end{array}$

\section{Spesifikasi Material yang Digunakan}

Pada penelitian ini material ABS yang digunakan yaitu:ABS LG Chem HI 100 Kategori: Polymer; Thermoplastik; ABS Polymer; Acrylonitrile Butadiene Styrene (ABS), Impact Grade, Molded

Tabel 3.2 Tabel Mechanical Property ABS LG Chem HI100

ABS LG HI 100

Tensile Strength @ Yield 37.278 N/mm2

Tensile Modulus $1608.84 \mathrm{~N} / \mathrm{mm} 2$

Elongation@ Yield

$4.12 \mathrm{~mm}$

Elongation@Break

$14.2 \mathrm{~mm}$

\section{Purchase Order Material ABS}

Berikut adalah data PO material ABS selama Januari 2015 hingga Juni 2015:

Tabel 3.4 PO Material ABS

\begin{tabular}{|c|c|c|c|c|c|c|c|c|c|}
\hline Tanggal PO & Jumlah (kg) & \multicolumn{2}{|c|}{ Harga } & \multicolumn{2}{|c|}{ Sub-Total } & \multicolumn{2}{|c|}{ Biava Pemesanan } & \multicolumn{2}{|r|}{ Total } \\
\hline Jan-15 & 25 & & 30,000 & $R R$ & 750,000 & RR & 75,000 & RR & 825,000 \\
\hline Feb-15 & 25 & $\mathrm{Rg}$ & 30,000 & $R_{R}$ & 750,000 & RR & 75,000 & $R_{R}$ & 825,000 \\
\hline Mar-15 & 25 & $\mathrm{Rg}$ & 30,000 & $R_{R}$ & 750,000 & RR & 75,000 & RR & 825,000 \\
\hline Apr-15 & 25 & $\mathrm{RR}$ & 30,000 & $R R$ & 750,000 & $\mathrm{RR}$ & 75,000 & $\mathrm{RR}$ & 825,000 \\
\hline Mei-15 & 25 & $\mathrm{Rg}$ & 30,000 & $R R$ & 750,000 & RR & 75,000 & RR & 825,000 \\
\hline Jun-15 & 25 & $\mathrm{Rg}$ & 30,000 & $\mathrm{RR}$ & 750,000 & $\mathrm{RR}$ & 75,000 & $\mathrm{RR}_{\mathrm{R}}$ & 825,000 \\
\hline Total & 150 & & & $R R$ & $4,500,000$ & RQ & 450,000 & & $4,950,000$ \\
\hline
\end{tabular}




\section{Proses Produksi}

Gambaran Umum Proses Produksi Plastik

Produk-produk hasil proses cetak injeksi yang menggunakan material ABS adalah:

Tabel 3.5 Spesifikasi Produk Plastik ABS

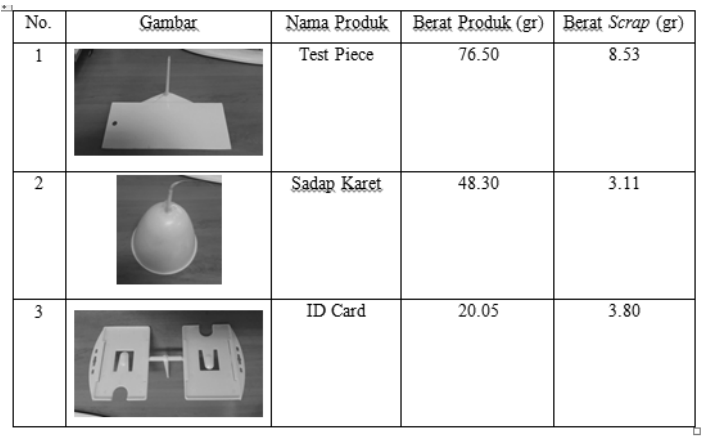

Scrap yang dihasilkan dari ketiga produk tersebut nantinya akan menjadi limbah plastik yang tidak lagi digunakan.

Berikut adalah data scrap yang dihasilkan dari ketiga produk:

Tabel 3.6 Scrap Plastik ABS Murni Februari-Juni 2015

\begin{tabular}{|lc|}
\hline Bulan & Jumlah Scrap $(\boldsymbol{g r})$ \\
\hline Februari & 17320 \\
Maret & 20730 \\
April & 23730 \\
Mei & 24500 \\
Juni & 3260 \\
\hline Total & $\mathbf{8 9 5 4 0}$ \\
\hline
\end{tabular}

\section{Proses Daur Ulang Plastik}

Sumber sampah plastik di Politeknik Manufaktur Astra ada dua yaitu dari produk-produk NG dan dari material drolling. Sampah-sampah plastik itu nantinya akan di proses daur ulang dengan langkah-langkahnya sebagai berikut:

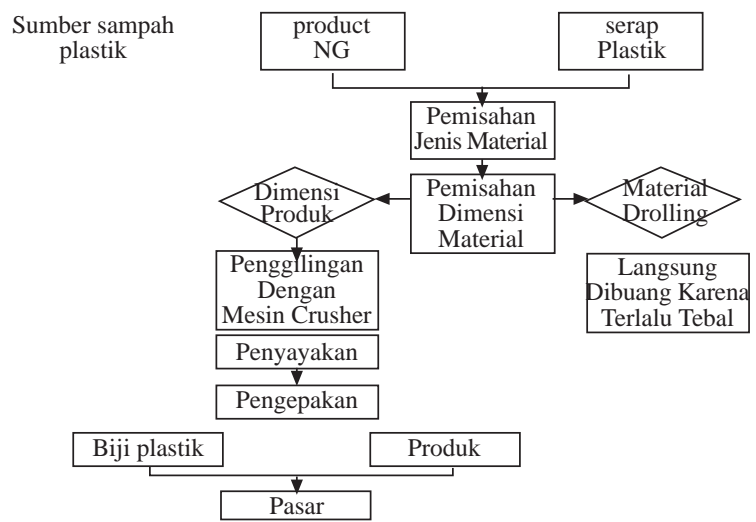

Gambar 3.6 Flow Process Daur Ulang Plastik

Dari proses daur ulang tersebut didapatkan hasil biji plastik dan debu. Berikut adalah data biji plastik yang bisa diproses kembali atau sudah tidak mengandung debu:

Tabel 3.7 Jumlah Biji Plastik Hasil Daur Ulang

\begin{tabular}{|ll|}
\hline Bulan & Jumlah Scrap (gr) \\
\hline Februari & 11250 \\
Maret & 12430 \\
April & 14230 \\
Mei & 12250 \\
Juni & 1950 \\
\hline Total & $\mathbf{5 2 1 1 0}$ \\
\hline
\end{tabular}

\section{Forecast Kebutuhan Material ABS}

Berikut ini data pemakaian material plastik tahun 2014 dan 2015:

Tabel 3.8 Data Pemakaian Material ABS 2014-2015

\begin{tabular}{|lll|}
\hline Bulan & $\mathbf{2 0 1 4}$ & $\mathbf{2 0 1 5}$ \\
\hline Januari & 25 & 25 \\
Februari & 25 & 25 \\
Maret & 25 & 25 \\
April & 25 & 25 \\
Mei & 50 & 25 \\
Juni & 25 & 25 \\
\hline Total & $\mathbf{1 7 5}$ & $\mathbf{1 5 0}$ \\
\hline
\end{tabular}

Dari data diatas maka dengan metode least square peramalan pemakaian material yang dilakukan perusahaan dapat dihitung sebagai berikut :

\section{Pola Data}

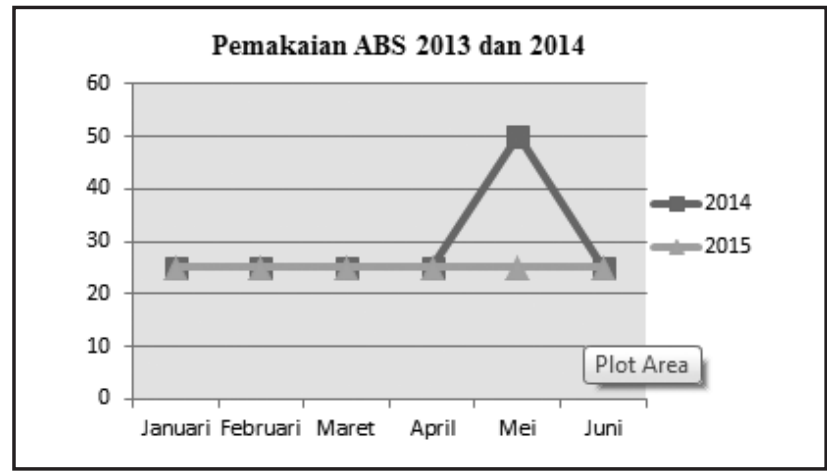

Gambar 3.7 Grafik Pemakaian Material ABS 2014-2015

Perhitungan Peramalan Pemakaian Material Dengan Metode Least Square 
Tabel 3.9 Peramalan Pemakaian Material ABS

\begin{tabular}{|c|c|c|c|c|c|}
\hline Bulan & Pemakaian & $\mathbf{t}$ & $\mathbf{d t}$ & $\mathbf{t}^{*} \mathbf{d t}$ & $\mathbf{t}^{\wedge} \mathbf{2}$ \\
\hline Januari & 25 & 1 & 25 & 25 & 1 \\
\hline Februari & 25 & 2 & 25 & 50 & 4 \\
\hline Maret & 25 & 3 & 25 & 75 & 9 \\
\hline April & 25 & 4 & 25 & 100 & 16 \\
\hline Mei & 50 & 5 & 50 & 250 & 25 \\
\hline Juni & 25 & 6 & 25 & 150 & 36 \\
\hline Januari & 25 & 7 & 25 & 175 & 49 \\
\hline Februari & 25 & 8 & 25 & 200 & 64 \\
\hline Maret & 25 & 9 & 25 & 225 & 81 \\
\hline April & 25 & 10 & 25 & 250 & 100 \\
\hline Mei & 25 & 11 & 25 & 275 & 121 \\
\hline Juni & 25 & 12 & 25 & 300 & 144 \\
\hline Jumlah & $\mathbf{3 2 5}$ & $\mathbf{7 8}$ & $\mathbf{3 2 5}$ & $\mathbf{2 0 7 5}$ & $\mathbf{6 5 0}$ \\
\hline
\end{tabular}

\section{Mencari Nilai a dan b}

Persamaan linier regresi peramalan didapatkan dengan mengeliminasi persamaan:

$325=12 \mathrm{a}+78 \mathrm{~b}$

$2075=78 a+650 b$

Menghasilkan nilai $\mathrm{a}=28.788 \mathrm{~b}=-0.262$

Maka y' $=28.788-0.262 \mathrm{t}$

\section{Standard Error of Estimate}

Tabel 3.10 Tabel SEE

\begin{tabular}{|c|c|c|c|}
\hline $\mathbf{t}$ & $\mathbf{y}$ & $\mathbf{y}^{\prime}$ & $\left(\mathbf{y}-\mathbf{y}^{\prime}\right)^{\wedge}$ \\
\hline 1 & 25 & 25.38 & 0.14 \\
\hline 2 & 25 & 25.12 & 0.01 \\
\hline 3 & 25 & 24.85 & 0.02 \\
\hline 4 & 25 & 24.59 & 0.17 \\
\hline 5 & 50 & 24.33 & 658.96 \\
\hline 6 & 25 & 24.07 & 0.87 \\
\hline 7 & 25 & 23.81 & 1.43 \\
\hline 8 & 25 & 23.54 & 2.12 \\
\hline 9 & 25 & 23.28 & 2.96 \\
\hline 10 & 25 & 23.02 & 3.93 \\
\hline 11 & 25 & 22.76 & 5.03 \\
\hline 12 & 25 & 22.49 & 6.28 \\
\hline Jumlah & & & 681.91 \\
\hline
\end{tabular}

Standard Error of Estimate =

$$
\overline{\frac{(y 1-y 2)^{2}}{n-f}}=\overline{\frac{681.91}{11}}=7.87 \text { unit }
$$

5. Perhitungan Peramalan Pemakaian Material Dengan Metode Simple Average
Tabel 3.11 Tabel Peramalan Metode Simple Averagedan SEE

\begin{tabular}{|c|c|c|}
\hline$y$ & $y^{\prime}$ & $\left(y^{\prime}-y\right)^{\wedge} 2$ \\
\hline 25 & & \\
\hline 25 & 25 & 0 \\
\hline 25 & 25 & 0 \\
\hline 25 & 25 & 0 \\
\hline 50 & 25 & 625 \\
\hline 25 & 30 & 25 \\
\hline 25 & 29.17 & 17.36 \\
\hline 25 & 28.57 & 12.76 \\
\hline 25 & 28.13 & 9.77 \\
\hline 25 & 27.78 & 7.72 \\
\hline 25 & 27.50 & 6.25 \\
\hline 25 & 27.27 & 5.17 \\
\hline & 27.08 & \\
\hline Jumlah & 709.01 \\
\hline
\end{tabular}

\section{Standard Error of Estimate =}

$$
\frac{(y 1-y 2)^{2}}{n-f}=\overline{\frac{709.01}{11}}=8.03 \text { unit }
$$

Melihat nilai SEE dari dua metode yang digunakan, maka peramalan permintaan untuk tahun yang akan datang menggunakan metode least square dengan nilai SEE terkecil yaitu 7.87 unit. Berikut adalah rumus yang digunakan untuk peramalan bulan ke 13-24 sesuai dengan metode least square: $\mathbf{y}^{\prime}=\mathbf{2 8 . 7 8 8} \mathbf{- 0 . 2 6 2 t}$

6. Tabel Hasil Peramalan Untuk 2 Bulan Ke Depan

Tabel 3.12 Tabel Hasil Peramalan untuk Tahun 2016 dan 2017

\begin{tabular}{|lcc|}
\hline Bulan & Periode & Pemakaian $\left(\mathbf{y}^{\prime}\right)$ \\
\hline Januari & 13 & 25.38 \\
Februari & 14 & 25.12 \\
Maret & 15 & 24.85 \\
April & 16 & 24.59 \\
Mei & 17 & 24.33 \\
Juni & 18 & 24.07 \\
Januari & 19 & 23.81 \\
Februari & 20 & 23.54 \\
Maret & 21 & 23.28 \\
April & 22 & 23.02 \\
Mei & 23 & 22.76 \\
Juni & 24 & 22.49 \\
\hline Jumlah & & $\mathbf{2 8 7 . 2 4}$ \\
\hline
\end{tabular}


Berdasarkan hasil peramalan di atas maka kebutuhan material ABS untuk tahun 2016 adalah $148.34 \mathrm{~kg}$ dan 2017 adalah $138.90 \mathrm{~kg}$.

\section{Penetapan EOQ}

Di bawah ini adalah biaya variable pembelian material ABS:

Tabel 3.13 Biaya-Biaya Variabel Pembelian Material ABS

\begin{tabular}{|lllr|}
\hline Kebutuhan 1 tahun (D) & & & \\
\hline Nilai persediaan & $\begin{array}{l}\text { jumlah unit pesanan x } \\
\text { harga beli (Rp. 30000) }\end{array}$ & $\begin{array}{l}148,34 \mathrm{~kg} \\
\text { Rp. }\end{array}$ & 718.094 .41 \\
\hline Biaya pemesanan (S) & 10\% x Harga & Rp. & 75.000 .00 \\
\hline Biaya Penyimpanan (H) & $5 \%$ x biaya pemesan & Rp. & 3.750 .00 \\
\hline
\end{tabular}

Berdasarkan data di atas, maka dapat ditentukan Economic Order Quantity (EOQ) adalah sebagai berikut:

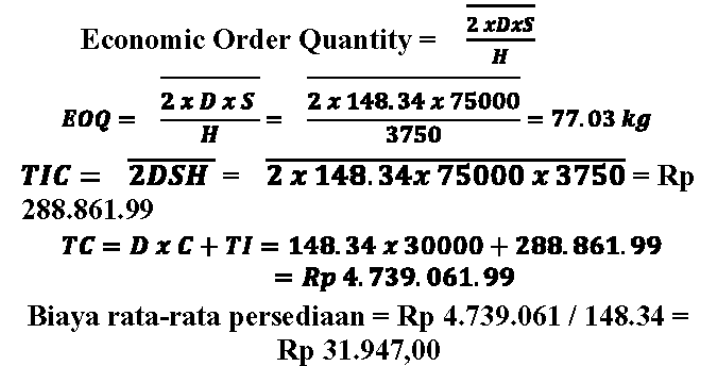

Tabel 3.14 Perhitungan Pemesanan Optimum Melalui Pendekatan Tabel

\begin{tabular}{|c|c|c|c|c|}
\hline Uraian. & 27 & 52 & 77 & 102 \\
\hline $\begin{array}{l}\text { Biaya Pemesanan } \\
\text { (D/Q }) \times \text { RR } 75000\end{array}$ & Rp. $\quad 398,944.44$ & Bp. $\quad 207,144.23$ & $\begin{array}{ll}\mathrm{Rp} & 139,889.61 \\
\end{array}$ & Bp $\quad 105,602.94$ \\
\hline $\begin{array}{l}\text { Biaya } \\
\text { Penyimpanan } \\
(Q / 2) \times R R 3750\end{array}$ & $\operatorname{Bp} \quad 50,625.00$ & $97,500.00$ & Rp $\quad 144,375.00$ & Rp $\quad 191,250.00$ \\
\hline TIC & RP $\quad 449,569.44$ & \begin{tabular}{|ll} 
Rp & $304,644.23$ \\
\end{tabular} & $\begin{array}{ll}\mathrm{RP} & 284,264.61 \\
\end{array}$ & \begin{tabular}{|ll} 
RR & $296,852.94$ \\
\end{tabular} \\
\hline $\begin{array}{l}\mathrm{D} \times \mathrm{C}(143.63 \mathrm{x} \\
30000)\end{array}$ & Rp $4,308,600.00$ & $308,600.00$ & $308,600.00$ & Rp $4,308,600.00$ \\
\hline Total Cost & Rp 5,207,738.89 & \begin{tabular}{|l|} 
Rp $4,917,888.46$ \\
\end{tabular} & $\operatorname{Rp} 4,877,129.22$ & Rp 4,902,305.88 \\
\hline
\end{tabular}

Tabel 3.14 menunjukkan bahwa persediaan optimum adalah $77.03 \mathrm{~kg}$ karena persediaan pada titik tersebut akan memberikan konseluensi biaya paling murah. Data dalam table 3.14 khususnya mengenai biaya variable sediaan, dapat dilihat pada gambar 3.14 berikut:

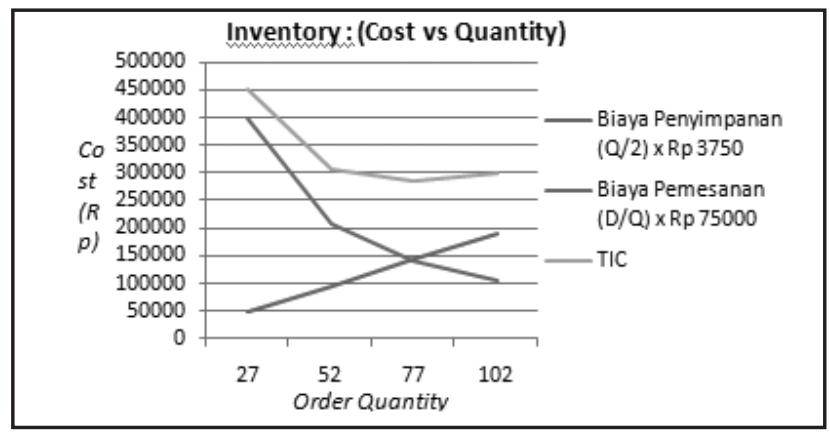

Gambar 3.8 Grafik EOQ

Dari perhitungan EOQ di atas, dapat diketahui bahwa besarnya pembelian yang ekonomis adalah sebanyak $77.03 \mathrm{~kg}$.

\section{Pengujian Material Plastik Daur Ulang}

Untuk mengetahui pengaruh material daur ulang terhadap kekuatan mekanik material, maka langkah yang diambil penulis adalah dengan mengujikan spesimen yang memiliki komposisi material daur ulang yang berbeda-beda untuk mengeta-hui pada komposisi berapa saja yang menunjukkan perubahan sifat yang drastis

Data yang dihasilkan dari pengujian tarik material ABS LG Chem HI 100.Pengujian tarik pada material ABS LG Chem HI 100 dilakukan dengan 2 kecepatan pengujian yaitu dengan kecepatan $5 \mathrm{~mm} / \mathrm{min}$ dan $50 \mathrm{~mm} / \mathrm{min}$.

Tabel 3.15 Data kekuatan mekanik ABS dengan kecepatan pengujian $5 \mathrm{~mm} / \mathrm{min}$

\begin{tabular}{|c|c|c|c|c|c|}
\hline MATERIAL & $\begin{array}{c}\text { Stress @ } \\
\text { Yield } \\
\left(\mathrm{N} / \mathrm{mm}^{2}\right)\end{array}$ & $\begin{array}{c}\text { Elong@ } \\
\text { Yield } \\
(\mathrm{mm})\end{array}$ & $\begin{array}{c}\text { Strain } \\
\text { @ Yield } \\
(\%)\end{array}$ & $\begin{array}{c}\text { Elong@ } \\
\text { Break } \\
\text { (mm) }\end{array}$ & $\begin{array}{c}\text { Modulus } \\
\text { Young } \\
\left(\mathrm{N} / \mathrm{mm}^{2}\right) \\
\left(10^{2}\right)\end{array}$ \\
\hline ABS MURNI & 30.618 & 3.316 & 2.0097 & 15.922 & 18.365 \\
\hline ABS DU $5 \%$ & 28.059 & 3.334 & 2.0206 & 15.876 & 18.749 \\
\hline ABS DU $10 \%$ & 29.946 & 3.358 & 2.3551 & 15.142 & 18.967 \\
\hline ABS DU $20 \%$ & 30.057 & 3.432 & 2.0802 & 14.584 & 18.304 \\
\hline ABS DU $30 \%$ & 30.258 & 3.436 & 2.1034 & 14.786 & 17.445 \\
\hline ABS DU $40 \%$ & 30.388 & 3.568 & 2.1624 & 11.466 & 15.977 \\
\hline ABS DU $50 \%$ & 30.392 & 3.772 & 2.2861 & 13.500 & 15.550 \\
\hline ABS DU $60 \%$ & 30.119 & 3.608 & 2.1868 & 12.686 & 14.383 \\
\hline ABS DU $70 \%$ & 30.281 & 3.534 & 2.1416 & 12.888 & 14.660 \\
\hline ABS DU $80 \%$ & 30.262 & 3.558 & 2.1563 & 12.722 & 14.824 \\
\hline ABS DU $90 \%$ & 26.312 & 3.538 & 1.8170 & 11.724 & 14.587 \\
\hline ABS DU $100 \%$ & 30.765 & 3.554 & 2.1442 & 13.332 & 14.598 \\
\hline
\end{tabular}

Tabel diatas adalah data pengujian tarik yang dilakukan terhadap spesimen ABS dengan kecepatan pengujian $5 \mathrm{~mm} / \mathrm{min}$.

Tabel 3.16 Data kekuatan mekanik ABS dengan kecepatan pengujian $50 \mathrm{~mm} / \mathrm{min}$

\begin{tabular}{|l|r|r|r|r|r|}
\hline MATERIAL & $\begin{array}{c}\text { Stress@ } \\
\text { Yiled } \\
\left(\mathbf{N / m m}^{2}\right)\end{array}$ & $\begin{array}{c}\text { Elong } \\
\text { @Yield } \\
(\mathbf{m m})\end{array}$ & $\begin{array}{c}\text { Strain@ } \\
\text { Yield }(\%)\end{array}$ & $\begin{array}{c}\text { Elong@@ } \\
\text { Break }(\mathbf{m m})\end{array}$ & $\begin{array}{c}\text { Modulus } \\
\text { Young } \\
\left(\mathbf{N} / \mathbf{m m}^{2}\right)(\mathbf{1 0})\end{array}$ \\
\hline ABS MURNI & 35.667 & 3.843 & 2.3293 & 12.487 & 17.979 \\
\hline ABS DU 5\% & 35.444 & 3.883 & 2.3535 & 10.233 & 17.522 \\
\hline ABS DU 10\% & 35.686 & 3.897 & 2.3616 & 10.053 & 18.835 \\
\hline ABS DU 20\% & 35.530 & 3.803 & 2.3051 & 11.970 & 18.564 \\
\hline ABS DU 30\% & 35.682 & 3.893 & 2.3596 & 12.497 & 17.450 \\
\hline ABS DU 40\% & 35.925 & 3.930 & 2.3818 & 12.210 & 15.358 \\
\hline ABS DU 50\% & 35.757 & 3.853 & 2.3353 & 11.050 & 18.486 \\
\hline ABS DU 60\% & 35.741 & 3.853 & 2.3354 & 10.943 & 16.383 \\
\hline ABS DU 70\% & 35.615 & 3.717 & 2.4168 & 10.403 & 17.443 \\
\hline ABS DU 80\% & 35.860 & 3.880 & 2.3515 & 10.747 & 16.226 \\
\hline ABS DU 90\% & 36.016 & 3.890 & 2.3683 & 11.010 & 17.001 \\
\hline ABS DU 100\% & 36.577 & 3.930 & 2.3818 & 9.357 & 16.499 \\
\hline
\end{tabular}

Tabel diatas adalah tabel kekuatan mekanik material ABS yang diuji dengan kecepatan 50 $\mathrm{mm} / \mathrm{min}$ sesuai dengan kecepatan pengujian yang digunakan pada data pembandingnya.
ANALISA DAN PEMBAHASAN
4.1 Analisa Penggunaan Material Plastik Daur Ulang 
4.1.1Perbandingan Scrap Terpakai dan Terbuang Berikut adalah perbandingan antara jumlah material plastik ABS yang terpakai, yang bisa didaur ulang dan yang terbuang:

Tabel 4.1 Tabel Perbandingan Jumlah Scrap Total dan yang Masih Bisa Terpakai

\begin{tabular}{|lcc|}
\hline Bulan & Jumlah Scrap & $\begin{array}{c}\text { Jumlah Scrap } \\
\text { Terpakai }\end{array}$ \\
\hline Februari & 17320 & 11250 \\
Maret & 20730 & 12430 \\
April & 23730 & 14230 \\
Mei & 24500 & 12250 \\
Juni & 3260 & 1950 \\
\hline Total & $\mathbf{8 9 5 4 0}$ & $\mathbf{5 2 1 1 0}$ \\
\hline
\end{tabular}

Gambar 4.1 Grafik Jumlah Scrap Terpakai VS Terbuang

\section{Total Penghematan Akibat Penggunaan Material Daur Ulang}

Berikut adalah penghematan yang bisa terjadi dengan adanya pemanfaatan material plastik daur ulang:

Tabel 4.2 Tabel Penghematan Akibat Penggunaan Material Daur Ulang

\begin{tabular}{|c|c|c|c|c|c|c|}
\hline No & Bulan & $\begin{array}{c}\text { Jumlah } \\
\text { Scrap } \\
\text { Terpakai }\end{array}$ & Harg & Harga Dip & $\begin{array}{c}\text { Total } \\
\text { Penghematan } \\
\text { Dijual } \\
\end{array}$ & $\begin{array}{c}\text { Total } \\
\text { Penghematan } \\
\text { Dipakai } \\
\end{array}$ \\
\hline 1 & Februari & 11.25 & $\mathrm{Rp}_{3,000.00}$ & $\mathrm{Rp}_{2} 30,000.00$ & Rp $33,750.00$ & $\mathrm{Rp} 337,500.00$ \\
\hline 2 & Maret & 12.43 & Rp $3,000.00$ & $\mathrm{Rp} 30,000.00$ & $\mathrm{Rp} 37,290.00$ & $\mathrm{Rp} 372,900.00$ \\
\hline 3 & April & 14.23 & Rp $3,000.00$ & $\mathrm{Rp} 30,000.00$ & Rp42,690.00 & $\mathrm{Rp}_{426,900.00}$ \\
\hline 4 & Mei & 12.25 & $\operatorname{Rp} 3,000.00$ & $\operatorname{Rp} 30,000.00$ & Rp $36,750.00$ & Rp $367,500.00$ \\
\hline 5 & Juni & 1.95 & Rp $3,000.00$ & $\mathrm{Rp} 30,000.00$ & $\operatorname{Rp} 5,850.00$ & $\mathrm{Rp}_{58,500.00}$ \\
\hline \multicolumn{5}{|c|}{ Total } & Rp $156,330.00$ & Rp $1,563,300.00$ \\
\hline
\end{tabular}

\section{Keterangan :}

a. Harga dijual : Harga per kilo apabila material plastik daur ulang tersebut dijual keluar atau dengan kata lain tidak lagi digunakan di dalam Politeknik Manufaktur Astra.

b. Harga dipakai : Harga apabila limbah material plastik dipakai kembali dengan asumsi bahwa dengan menggunakan material plastik daur ulang maka perusahaan bisa menghemat pembelian material sebanyak jumlah scrap yang digunakan.

Berdasarkan data di atas maka dapat diketahui bahwa pemanfaatan limbah material plastik dengan cara di daur ulang bisa menghemat 10 kali lebih besar daripada dijual kembali.

\section{Analisa Data Peramalan dan Grafik EOQ}

Berikut adalah grafik EOQ:

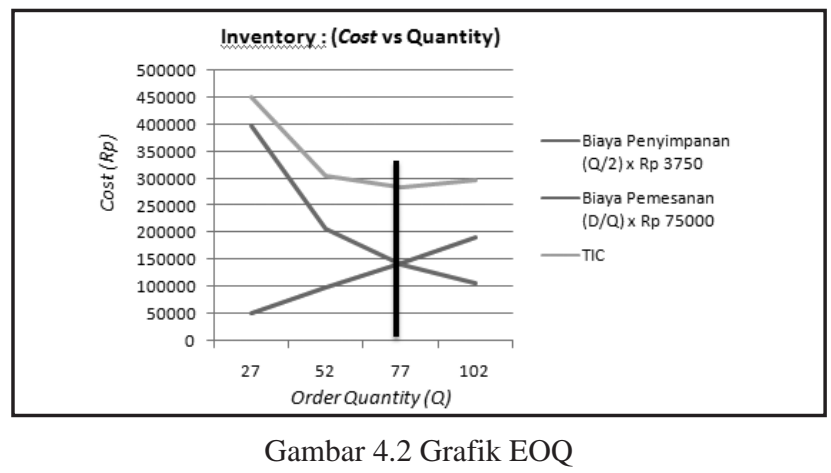

Berdasarkan grafik EOQ diatas diketahui bahwa nilai minimal order yang harus dilakukan perusahaan adalah $77.03 \mathrm{~kg}$ per order. Untuk memenuhi syarat minimal order dan peramalan kebutuhan material plastik tahun 2016 maka perusahaan akan melakukan order $75 \mathrm{~kg}$ per order. 4.3 Analisa Total Biaya Persediaan Material ABS Berikut adalah perbandingan antara total biaya penyediaan material AuBS tahun 2015 dengan metode lama dan total biaya penyediaan material ABS dengan metode EOQ :

Tabel 4.3 Tabel Perbandingan Biaya Total Persediaan Material ABS

\begin{tabular}{|c|c|c|c|c|c|c|}
\hline \multicolumn{7}{|c|}{ Total Biaya Persediaan Material ABS tahun 2015} \\
\hline No PO & Jumlah & Harga & Sub Total & Biaya Pemesanan & Biaya Penyimpanan & Total \\
\hline 1 & 25 & 30000 & 750000 & 75000 & 46875 & 871875 \\
\hline 2 & 25 & 30000 & 750000 & 75000 & 46875 & 871875 \\
\hline 3 & 25 & 30000 & 750000 & 75000 & 46875 & 871875 \\
\hline 4 & 25 & 30000 & 750000 & 75000 & 46875 & 871875 \\
\hline 5 & 25 & 30000 & 750000 & 75000 & 46875 & 871875 \\
\hline 6 & 25 & 30000 & 750000 & 75000 & 46875 & 871875 \\
\hline \multicolumn{6}{|c|}{ Total Biaya Persediaan Selama 1 Tahun } & Rp 5.231.250 \\
\hline \multicolumn{7}{|c|}{ Total Biaya Persediaan Material ABS Dengan Metode EOQ } \\
\hline No PO & Jumlah & Harga & Sub Total & Biaya Pemesanan & Biaya Penyimpanan & Total \\
\hline 1 & 75 & 30000 & 2250000 & 75000 & 140625 & 2465625 \\
\hline 2 & 75 & 30000 & 2250000 & 75000 & 140625 & 2465625 \\
\hline \multicolumn{6}{|c|}{ Total Biaya Persediaan Selama 1 Tahun } & Rp 4.931.250 \\
\hline
\end{tabular}

Penghematan biaya persediaan material plastik ABS tahun 2015 dipandingkan tahun depan yang menggunakan metode EOQ ditunjukkan pada grafik dibawah ini:

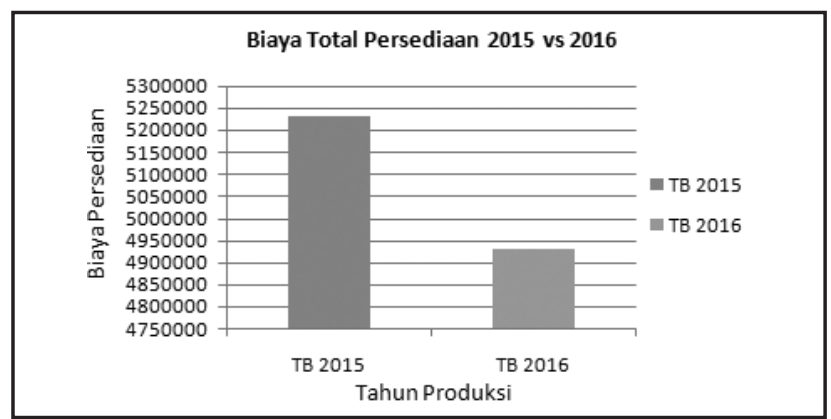

Gambar 4.3 Grafik Biaya Persediaan Material Tahun 2015 vs 2016 
Setelah kita menghitung total biaya persediaan, baik yang ditetapkan oleh perusahaan selama ini maupun dengan penerapan metode EOQ, maka dapat diketahui bahwa terjadi penurunan biaya sebesar $5.73 \%$.

EOQ ternyata dapat meminimkan biaya persediaan selama setahun sebesar:

\section{Rp 5.231.250 - Rp 4.931.250 = Rp 300.000}

Sehingga pembelian dengan menggunakan metode EOQ adalah pembelian yang efisien dan meminimumkan biaya persediaan bagi perusahaan.

\subsection{Analisa Sifat Material Plastik Daur Ulang}

Pengujian tarik pada material ABS LG Chem HI 100 dilakukan dengan 2 kecepatan pengujian yaitu dengan kecepatan $5 \mathrm{~mm} / \mathrm{min}$ dan $50 \mathrm{~mm} / \mathrm{min}$.

Dari kelima analisa diatas maka komposisi material ABS daur ulang yang bisa untuk diproses kembali mulai dari $0 \%$ hingga $100 \%$ pada daur ulang pertama karena sifat mekanis yang dihasilkan dari pengujian tarik terhadap material daur ulang pertama hampir sama dengan sifat aslinya atau dengan kata lain pencampuran material daur ulang tidak terlalu berpengaruh pada perubahan sifat material ABS seperti yang terlihat pada grafik di bawah ini:

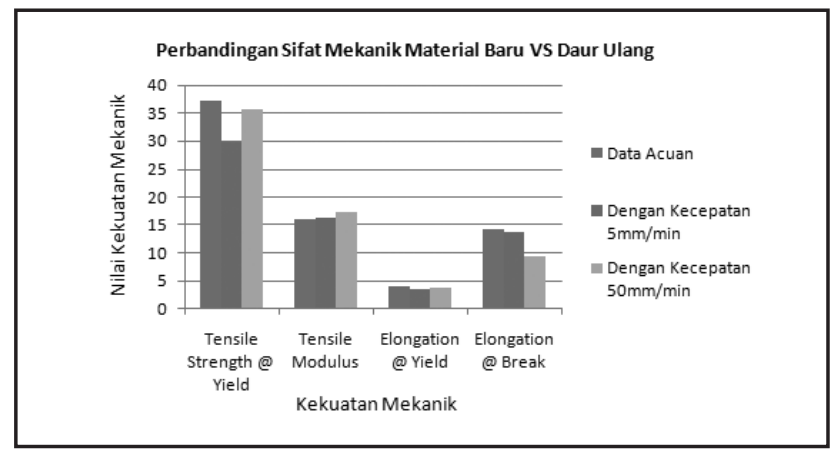

Gambar 4.6 Grafik Perbandingan Sifat Mekanik Material Baru VS Daur Ulang

\subsection{Analisa Total Biaya Persediaan Material ABS Setelah Penggunaan Material Daur Ulang}

Dari data untuk memenuhi kebutuhan tahun 2016, perusahaan harus membeli material ABS sebanyak150 kg.Dengan adanya pemanfaatan limbah material ABS sebanyak $52.11 \mathrm{~kg}$ maka kebutuhan pembelian material ABS baru menjadi 97.89 $\mathrm{kg}$ atau $100 \mathrm{~kg}$. Untuk mengetahuai nilai EOQ baru setelah diketahui bahwa kebutuhan material baru hanya $100 \mathrm{~kg}$, maka penulis melakukan lagi perhitungan nilai EOQ dengan kebutuhan 1 tahun $97.89 \mathrm{~kg}$. Berikut adalah perhitungannya:
Tabel 4.6 Biaya-Biaya Variabel Pembelian Materil ABS

\begin{tabular}{|c|c|c|}
\hline Kebutuhan 1 tahun (D) & & $150-52.11-97.89 \mathrm{~kg}$ \\
\hline Biaya pemesanan $(\mathrm{S})$ & $10 \%$ x Harga & $\begin{array}{ll}\text { Rp. } & 75.000 .00 \\
\end{array}$ \\
\hline Biaya Penyimpanan $(\mathrm{H})$ & $5 \% \mathrm{x}$ biaya pemesan & 3.750 .00 \\
\hline
\end{tabular}

Berdasarkan data di atas, maka dapat ditentukan besarnya jumlah pembelian bahan baku yang ekonomis dengan menggunakan rumus (formula approach)Economic Order Quantity $(E O Q)$ adalah sebagai berikut:

$$
\begin{aligned}
& \text { Economic Order Quantity }=\overline{\frac{2 x D x S}{H}} \\
& E O Q=\frac{\overline{2 \times D \times S}}{H}=\frac{\overline{2 \times 97.89 \times 75000}}{3750}=62.57 \mathrm{~kg} \\
& T I C=\overline{2 D S H}=\overline{2 \times 97.89 x 75000 \times 3750}=\mathrm{Rp} \\
& T C=D x C+T I=97.89 \times 30000+234.655,33 \\
& =R p 3.171 .355,33 \\
& \text { Biaya rata-rata persediaan }=R p 3.171 .355,33 \text { / } \\
& 97.89=\text { Rp 32.397, } 13
\end{aligned}
$$

\begin{tabular}{|c|c|c|c|c|}
\hline Uraian & 50 & 62.57 & 75 & 100 \\
\hline $\begin{array}{l}\text { Biaya Pemesanan } \\
\text { (D/Q) x Rp } 75000\end{array}$ & Rp $\quad 215,430.00$ & $\mathrm{Rp} \quad 172,151.19$ & $\operatorname{Rp} \quad 143,620.00$ & $\operatorname{Rp} \quad 107,715.00$ \\
\hline $\begin{array}{l}\text { Biaya } \\
\text { Penyimpanan } \\
\text { (Q/2) × Rp } 3750\end{array}$ & $\mathrm{Rp} \quad 93,750.00$ & $117,318.75$ & $140,625.00$ & Rp $\quad 187,500.00$ \\
\hline TIC & Rp $\quad 309,180.00$ & Rp $\quad 289,469.94$ & Rp $\quad 284,245.00$ & $\mathrm{Rp} \quad 295,215.00$ \\
\hline $\begin{array}{l}\text { Dx C (143.63x } \\
30000)\end{array}$ & $08,600.00$ & $308,600.00$ & Rp 4,308,600.00 & $\operatorname{Rp} 4,308,600.00$ \\
\hline Total Cost & $\operatorname{Rp} 4,926,960.00$ & Rp $4,887,539.88$ & Rp $4,877,090.00$ & Rp 4,899,030.00 \\
\hline
\end{tabular}

Tabel 4.7 Perhitungan Pemesanan Optimum Melalui Pendekatan Tabel

Data dalam table 4.7 khususnya mengenai biaya variable sediaan, dapat dilihat pada gambar 4.7 berikut:

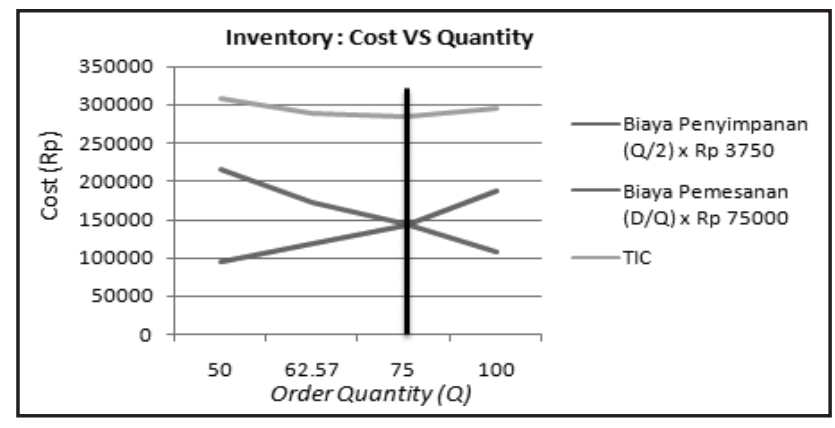

Gambar 4.7 Grafik EOQ Setelah Pemakaian Daur Ulang

Berdasarkan grafik EOQ diatas diketahui bahwa nilai minimal order yang harus dilakukan perusahaan adalah $75 \mathrm{~kg}$ per order.

Berikut adalah variabel penghematan total biaya penyediaan material ABS dengan metode EOQ dan pemanfaatan limbah material plastik: 
Tabel 4.8 Tabel Variabel Penghematan Yang Terjadi

\begin{tabular}{|l|c|}
\hline Kebutuhan material ABS 2016 & $150 \mathrm{~kg}$ \\
\hline Jumlah Scrap yang bisa dipakai kembali & $52.11 \mathrm{~kg}$ \\
\hline Kebutuhan material ABS 2016 setelah pemanfaatan limbah & $97.89 \mathrm{~kg}$ \\
\hline Karena ada minimal order, maka minimal order 2016 & $\mathbf{1 0 0 ~} \mathrm{kg}$ \\
\hline EOQ setelah adanya pemanfaatan limbah & $75 \mathrm{~kg}$ \\
\hline Total Biaya Persediaan Material ABS Tanpa EOQ & $\mathrm{Rp} 5,231,250$ \\
\hline $\begin{array}{l}\text { Total Biaya Persediaan Material ABS Dengan EOQ tanpa Pemanfaatan } \\
\text { Limbah Plastik }\end{array}$ & Rp $4,931,250$ \\
\hline
\end{tabular}

Maka setelah adanya pemanfaatan limbah plastik dan penggunaan metode EOQ, berikut adalah biaya total persediaan material ABS:

Tabel 4.9 Tabel Biaya Total Persediaan Material ABS Setelah Ada EOQ dan Pemanfaatan Limbah Plastik

\begin{tabular}{|c|c|c|c|c|c|c|}
\hline \begin{tabular}{|l|} 
No PO \\
\end{tabular} & Jumlah & Harga & \begin{tabular}{|l|} 
Sub Total \\
\end{tabular} & \begin{tabular}{|l} 
Biaya Pemesanan \\
\end{tabular} & Biaya Penyimpanan & Total \\
\hline 1 & 75 & 30000 & 2250000 & 75000 & 140625 & 2465625 \\
\hline 2 & 25 & 30000 & 750000 & 75000 & 46875 & 871875 \\
\hline & \multicolumn{5}{|c|}{ Total Biaya Persediaan Selama 1 Tahun } & $\operatorname{Rp} \mathbf{3 . 3 3 7 . 5 0 0}$ \\
\hline
\end{tabular}

Tabel 4.9 merupakan tabel perhitungan total biaya persediaan material ABS selama setahun dengan EOQ dan sudah memanfaatkan scrap material ABS. Dari tabel dapat diketahui bahwa dengan menggunakan metode EOQ dan memanfaatkan scrap material ABS dapat dilakukan penghematan biaya persediaan material ABS sebanyak: Rp 5.231.250 - Rp 3.337.500 = Rp 1.893.750

\section{KESIMPULAN}

Berdasarkan penelitian yang sudah dilakukan maka dapat diambil beberapa kesimpulan diantaranya yaitu:

Pemanfaatan limbah plastik guna meningkatkan efisiensi material plastik dengan melakukan proses daur ulang dalam rangka mengurangi dampak lingkungan hidup dengan sistem manufaktur berkelanjutan sangat dapat dilakukan karena sifat material plastik (yang dimaksud disini adalah ABS) pada daur ulang pertama tidak drastis berubah dari sifat aslinya yang sudah dibuktikan dengan adanya pengujian tarik.

Dengan menggunakan metode EOQ untuk proses persediaan material plastik ABS sebelum adanya pemanfaatan limbah plastik di Politeknik Manufaktur Astra dapat diketahui bahwa pemesanan material dapat dilakukan hanya 2 kali dengan jumlah sekali pesan sesuai EOQ adalah $75 \mathrm{~kg}$ dan hal tersebut dapat menghemat biaya sebesar Rp 300.000,00.

Dengan adanya pemanfaatan limbah material plastik dan penggunaan metode EOQ dalam proses pemesanan maka total penghematan yang bisa dilakukan sebesar Rp 1.893.750.

\section{DAFTAR PUSTAKA}

Haming, Murdifin dan Mahfud. (2012), Manajemen Produksi Modern Operasi Manufaktur dan Jasa Buku 2, Bumi Aksara, Jakarta.

Hartini,Sri dan Kadarsah. (2010), Teknik Mencapai Produksi Optimal, Lubuk Agung, Bandung.

Mitchell, Philip. Tool And Manufacturing Engineers Handbook Volume 8 Plastic Part Manufacturing, TMEH.

Smallmam, R. (1999), Metalurgi Fisik Modern dan Rekayasa Material, Terj. Modern Physical Metallurgy \& Materials Engineering 6th Edition, Djaprie, Sriati (Pen.), Simarmata, Silvester Lameda (Ed.), Erlangga, Jakarta. 